\title{
Penanganan Limbah Elektronik (E-Waste) di Indonesia Berbasis Seni dan Drop Point
}

\author{
R. Hilary A Yoga ${ }^{1}$, Ningrum Suryaningsih ${ }^{2}$, Andri Setia Prabowo ${ }^{3}$, Joni Welman Simatupang ${ }^{4 *}$ \\ ${ }^{1,2,3,4}$ Program Studi Teknik Elektro, Fakultas Teknik, President University, Cikarang, 17550 - Indonesia \\ *Koresponden email: joniwsmtp@ president.ac.id
}

Diterima: 24 September 2020

Disetujui: 14 Oktober 2020

\begin{abstract}
Technological developments that increase the increase in electronic waste (e-waste) significantly. In Indonesia, the method of treating electronic waste by fire is not appropriate to apply, because electronic waste contains metals and will cause dangerous air pollution (for example: lead pollution). Electronic waste processing is different from organic waste that can be processed into fertilizer. Therefore, this condition can be categorized as an important problem, so it requires smart solutions that are fast and precise in processing. Handling this waste can be solved through several methods, namely e-waste banks and art integration. This method prioritizes artistic value, creativity, function, and in-depth knowledge of the waste, so that it can also take advantage of organizations or businesses that will bring profit and be environmentally friendly. This has also received support from the government through a program commonly known as Small and Medium Enterprises (UKM). The components that are usually buried, melted down, and destroyed will be sorted again based on their physicality so that it will facilitate the process of making art.
\end{abstract}

Keywords: comparative study, electronic waste, electronic waste hazard, electronic waste crafts, waste management

\begin{abstract}
Abstrak
Perkembangan teknologi yang pesat menyebabkan peningkatan limbah elektronik (e-waste) secara signifikan. Di Indonesia, metode pengolahan limbah elektronik dengan cara pembakaran dinilai kurang tepat bila diterapkan, sebab limbah elektronik pasti mengandung logam dan akan menimbulkan polusi udara yang berbahaya. Di samping itu, pengolahan limbah elektronik berbeda dengan sampah organik yang dapat diolah menjadi pupuk. Oleh karenanya, kondisi tersebut dapat dikategorikan sebagai permasalahan penting, sehingga membutuhkan solusi cerdas yang cepat dan tepat dalam pengolahannya. Penanganan limbah tersebut bisa dipecahkan melalui beberapa metode, yakni bank $e$-waste dan integrasi seni. Metode ini mengutamakan nilai seni, kreativitas, fungsi, dan pengetahuan mendalam tentang limbah tersebut, sehingga bisa juga dijadikan peluang mendirikan organisasi atau bisnis yang akan membawa keuntungan serta menjadi ramah lingkungan. Hal ini juga mendapat dukungan pemerintah melalui suatu program yang biasa dikenal dengan istilah Usaha Kecil Menengah (UKM). Komponen-komponen yang biasanya dikubur, dileburkan, dan dihancurkan akan dipilah kembali berdasarkan fisiknya sehingga akan mempermudah dalam proses pembuatan karya seni.

Kata Kunci: bahaya limbah elektronik, penanganan limbah, limbah elektronik, studi banding, kerajinan limbah elektronik
\end{abstract}

\section{Pendahuluan}

Percepatan pertumbuhan produsen elektronik serta perkembangan teknologinya telah merevolusi dunia, termasuk di Indonesia. Segala bidang juga telah ikut berevolusi. Salah satu contoh perkembangan teknologi elektronik dibidang informasi dan komunikasi adalah penggunaan ponsel pada menu Short Message Service (SMS) sebagai pengganti dari surat konvensional. Dengan adanya SMS, jarak tidak lagi menjadi penghalang bagi setiap orang untuk berkomunikasi dan bertukar informasi. Biayanya pun dapat dikatakan terjangkau oleh semua kalangan.

Dewasa ini, pertumbuhan produsen-produsen industri elektronik semakin meningkat pesat dalam persaingan pasar di Indonesia. Bahkan dalam satu jenis produk elektronik bisa memiliki 5-8 produsen. Dalam hitungan satu hari produsen mampu mengeluarkan ratusan ribu untuk satu jenis produk. Dalam waktu singkat pula, produsen mampu meningkatkan spesifikasi dari jenis peralatan elektronik tersebut untuk bersaing di pasar. Konsumen pun berlomba memiliki jenis divais elektronik dengan spesifikasi tertinggi [1]. Dengan begitu, divais elektronik yang sudah tertinggal spesifikasinya tidak lagi dilirik oleh 
para konsumen meskipun kondisinya masih normal dan layak pakai. Kita dapat menghitung berapa banyak elektronik yang kita miliki di rumah bahkan yang setiap hari kita bawa saat kita bepergian.

Di sisi lain, dengan berkembangnya produk-produk elektronik, masa pemakaian akan menjadi lebih pendek. Rentang pergantian barang-barang elektronik yang begitu cepat berakibat pada meningkatnya laju pertumbuhan sampah elektronik (e-waste). Limbah elektronik dapat dikatakan sebagai peralatan elektronik yang sudah usang karena kemajuan teknologi, perkembangan gaya hidup, dan kerusakan pada perangkat. Permasalahan limbah elektronik di Indonesia belum termasuk isu lingkungan yang menjadi fokus pemerintah dibandingkan dengan masalah banjir dan sampah logistik lainnya. Bila ditinjau lebih lanjut, sampah elektronik ini sangat berbahaya bagi lingkungan karena mengandung limbah timbal, merkuri, dan kromium, baterai, dan Cathode Ray Tubes (CRT) berwarna yang dapat mencemari lingkungan. Beberapa produk elektronik mengandung bahan yang berbahaya, tergantung pada kondisi dan massa jenis dari komponen tersebut. Lampu, ponsel, perangkat audio, televisi, baterai dan lain sebagainya jika dibuang secara sembarangan dapat melepaskan timah dan zat kimia lainnya ke tanah maupun air.

Kesalahan dalam mengelola limbah elektronik dari pengamatan yang kami lakukan dengan cara dibakar atau ditimbun di dalam tanah, begitupun juga yang dirusak atau dihancurkan lalu dibuang bersamaan limbah domestik lainnya. Bagaimana mengelola limbah elektronik yang benar dan tepat? Banyak dari komponen perangkat elektronik yang sebenarnya dapat digunakan, diperbaharui atau di daur ulang kembali, sehingga terciptanya limbah ramah lingkungan. Mengadopsi manajemen persediaan, proses modifikasi produksi, pengurangan volume, pemulihan dan penggunaan kembali dapat meminimalisasi limbah elektronik. Oleh karena itu, penelitian ini bertujuan untuk memberikan usulan solusi bagi limbah elektronik dengan cara memanfaatkan limbah tersebut sebagai barang yang memiliki nilai seni dan nilai kembali.

\section{Studi Literatur}

Tingkat konsumsi barang elektronik di Indonesia semakin meningkat. Keinginan seseorang terhadap barang elektronik telah menjadi kebutuhan utama untuk membantu pekerjaan mereka. Dari semua jenis barang elektronik yang dipergunakan, masing-masing memiliki umur pakai tertentu sehingga akan ada saatnya barang tersebut harus diganti atau dibuang. Dengan demikian barang tersebut akan menjadi limbah. Bayangkan saja dengan jumlah penduduk Indonesia saat ini, berapa banyak limbah elektronik yang akan dihasilkan setiap harinya?

\section{Bahaya limbah elektronik}

Aspek kesalahan pengolahan limbah elektronik, yaitu (1) minimnya informasi mengenai limbah elektronik kepada publik, (2) minimnya pemahaman perbedaan sampah rumah tangga dengan sampah/limbah elektronik dan tata cara pengelolaannya, dan (3) belum tersedianya ketentuan teknis, misalnya umur barang yang dapat diolah kembali. Mengingat bahaya tersebut, maka kita perlu belajar dari tiga negara di Asia Timur yaitu Jepang, Korea Selatan, dan Taiwan tentang bagaimana pengelolaan limbah elektronik secara baik dan efektif. Adapun bahaya atau dampak yang mungkin ditimbulkan dari pengelolaan yang salah terhadap limbah elektronik, dapat dilihat pada Tabel 1.

Tabel 1. Beberapa bahaya limbah elektronik apabila salah dalam pengelolaannya [2].

\begin{tabular}{|c|c|c|}
\hline Jenis Komponen & Unsur Terkandung & Dampak Pada Manusia \\
\hline Timah Solder & Timah $(\mathrm{Pb})$ & $\begin{array}{l}\text { Kerusakan pada saraf, sistem darah (efek juga } \\
\text { pada perkembangan otak) dan kerusakan ginjal }\end{array}$ \\
\hline $\begin{array}{l}\text { Resistor dan bahan } \\
\text { semi konduktor }\end{array}$ & Cadmium $(\mathrm{Cd})$ & Gagal ginjal dan hati \\
\hline Relay dan saklar & Mercury (Hg) & Gangguan pada otak, pernafasan, dan kulit \\
\hline Motherboard pada $P C$ & Beryllium (Be) & $\begin{array}{l}\text { Gangguan paru-paru dan kulit, serta penyakit pada } \\
\text { kulit (seperti kutil) }\end{array}$ \\
\hline $\begin{array}{l}\text { Cover, pelindung } \\
\text { bagian luar }\end{array}$ & Plastic, PVC & $\begin{array}{l}\text { Kerusakan lingkungan, kerusakan sistem imun } \\
\text { tubuh dan gangguan hormon }\end{array}$ \\
\hline $\begin{array}{l}\text { Cathode Ray Tube } \\
\text { (Tabung Sinar Katoda) }\end{array}$ & $\operatorname{Barrium}(\mathrm{Ba})$ & $\begin{array}{l}\text { Kelemahan otot, kerusakan hati, jantung dan } \\
\text { limpa }\end{array}$ \\
\hline
\end{tabular}




\section{Belajar pengolahan limbah elektronik dari tiga negara Asia Timur}

\section{a. Jepang}

\section{Latar Belakang Perundang-undangan}

Penanganan limbah elektronik sudah diatur dalam perundang-undangan yang dimiliki oleh Jepang. Jepang menangani limbah elektronik dengan dua cara. Pertama adalah Undang-Undang Promosi Pemanfaatan Sumber Daya yang Efektif (LPUR), yang bertujuan untuk meningkatkan solusi dalam mendaur ulang dan mengurangi timbunan limbah. Kedua adalah Undang-Undang Daur Ulang Jenis Peralatan Rumah Tangga Tertentu (LRHA), yang meminta tanggung jawab kepada produsen maupun konsumen yang berkaitan dengan daur ulang peralatan rumah tangga bekas. [3]

Struktur Pengumpulan dan Alokasi Biaya

Sejak Oktober 2003, daur ulang peralatan rumah tangga terutama komputer, tidak termasuk dalam LRHA. Secara sukarela produsen mengambil bagian dalam pengumpulan limbah dan mendaur ulang. Biaya untuk mengumpulkan dan mendaur ulang limbah yang dilakukan produsen, sudah diikutsertakan dalam harga produk. Untuk komputer bekas yang dibeli setelah Oktober 2003 konsumen tidak perlu membayar biaya untuk proses daur ulang karena sudah mengikuti undang-undang LRHA. Sedangkan komputer yang dibeli sebelum Oktober 2003, konsumen harus membayar biaya daur ulang saat pembuangan, sama seperti halnya untuk peralatan rumah tangga bekas lainnya (Gambar 1).

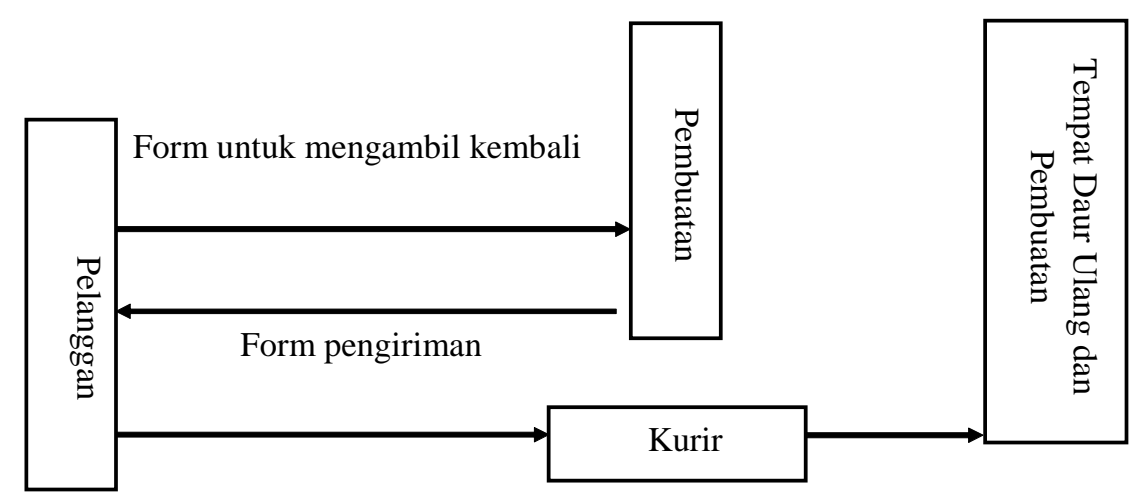

Gambar 1. Aliran perangkat komputer secara umum di Jepang [4].

LRHA bercermin pada prinsip EPR, yang memperluas tanggung jawab produsen dari tahap produksi sampai dengan masa habis pakai dan pengolahan kembali. Terkhusus, LRHA mengklarifikasi aliran "take-back" dan "take-in" peralatan elektronik yang berasal dari konsumen. Arus peralatan rumah tangga bekas dan peran aktor terkait di bawah LRHA dapat dilihat pada Gambar 2.

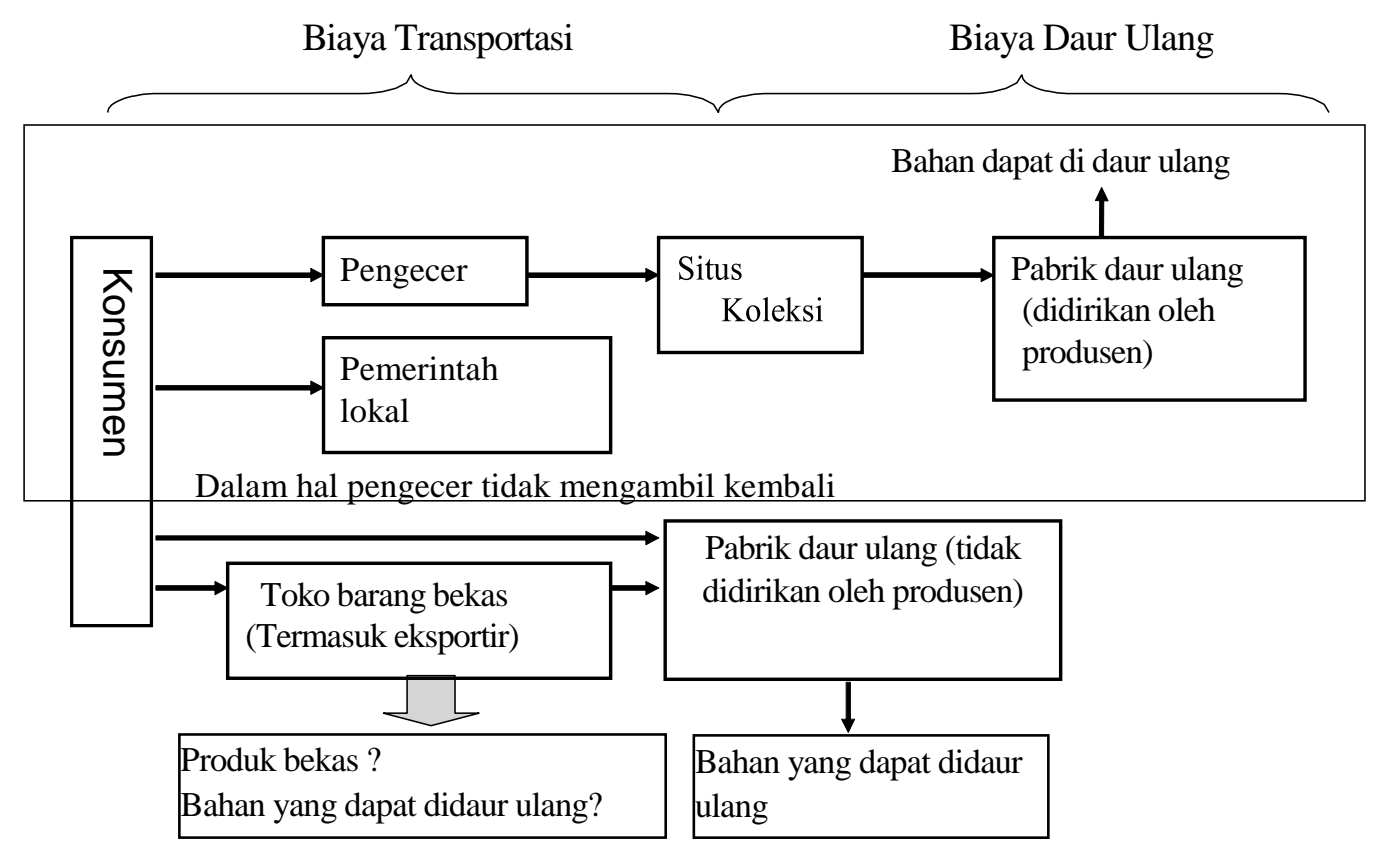

Gambar 2. Alur peralatan rumah tangga bekas dan peran aktor terkait LRHA di Jepang [5]. 
Menurut LRHA, produsen diwajibkan memiliki infrastruktur untuk mendaur ulang peralatan rumah tangga bekas. Namun, cara dan metode untuk melakukannya tidak diatur. Lalu bagaimana para produsen menanggapi situasi baru dengan terbentuknya undang-undang ini? Alasan Jepang memiliki dua jenis infrastruktur daur ulang adalah karena promosi persaingan antara produsen dan konsumen, untuk menghindari pelanggaran membuat undang-undang tersendiri. Selain itu, penilaian yang berbeda tentang cara mengurangi biaya termasuk pengumpulan dan daur ulang peralatan bekas [6]. Beban pemerintah kota untuk mendaur ulang limbah elektronik akan berkurang drastis. Alasan utama untuk menggabungkan sistem pembayaran pembuangan dianggap sebagai hal yang terkait dengan kekuatiran mengenai biaya tambahan untuk daur ulang yang menambah biaya peralatan rumah tangga [5].

\section{b. Korea Selatan}

\section{Latar Belakang Perundang-undangan}

Pengelolaan daur ulang di Korea Selatan dimulai dengan diberlakukannya undang-undang LRSR pada tahun 1992 untuk mengatasi tingginya peningkatan limbah elektronik pada tempat pembuangan akhir. Tindakan tersebut bertujuan untuk menjaga lingkungan dan sumber daya dengan mensuarakan daur ulang. Namun, hal yang tidak kalah pentingnya adalah menghindari efek yang akan terjadi dari sistem baru yaitu, untuk memberikan otonomi yang lebih besar kepada pemerintah daerah. Implementasi yang diusulkan dari sistem tersebut menimbulkan kekhawatiran bahwa kerusakan lingkungan yang disebabkan oleh kebijakan pembangunan kota akan meluas ke seluruh negeri dan peran serta pemerintah pusat dalam pengelolaan sampah akan berkurang fokusnya sehingga kemungkinan terjadi perselisihan antar wilayah akan meningkat. Perluasan dan peningkatan fasilitas pembuangan limbah yang dilakukan untuk mengurangi perselisihan, menghasilkan peningkatan substansial dalam anggaran pengelolaan limbah [7].

Pada tahun 1996 bergabung dengan OECD, kebijakan lingkungan di Korea Selatan telah secara langsung dipengaruhi oleh kebijakan yang berlaku di negara-negara barat. Dalam hal daur ulang, publikasi pemerintah OECD untuk implementasi EPR pada tahun 2001 sangat penting untuk peningkatan kebijakan lingkungan Korea Selatan. Pada Januari 2003, sistem Producer Recycling (PR), yang mendorong peran serta produsen dalam proses daur ulang limbah elektronik sebagai sistem yang substansial.

\section{Struktur Pengumpulan dan Alokasi Biaya}

Sistem $P R$ difungsikan untuk mendorong produsen bertanggung jawab dan berpartisipasi secara langsung dalam proses daur ulang limbah elektronik. Cara kerja sistem $P R$ sebagai berikut: Pertama, mempertimbangkan kinerja daur ulang dan jumlah daur ulang yang dilakukan oleh produsen. Dengan demikian, produsen diwajibkan untuk mengumpulkan alat rumah tangga bekas sesuai permintaan konsumen seperti yang terlihat pada Gambar 3.

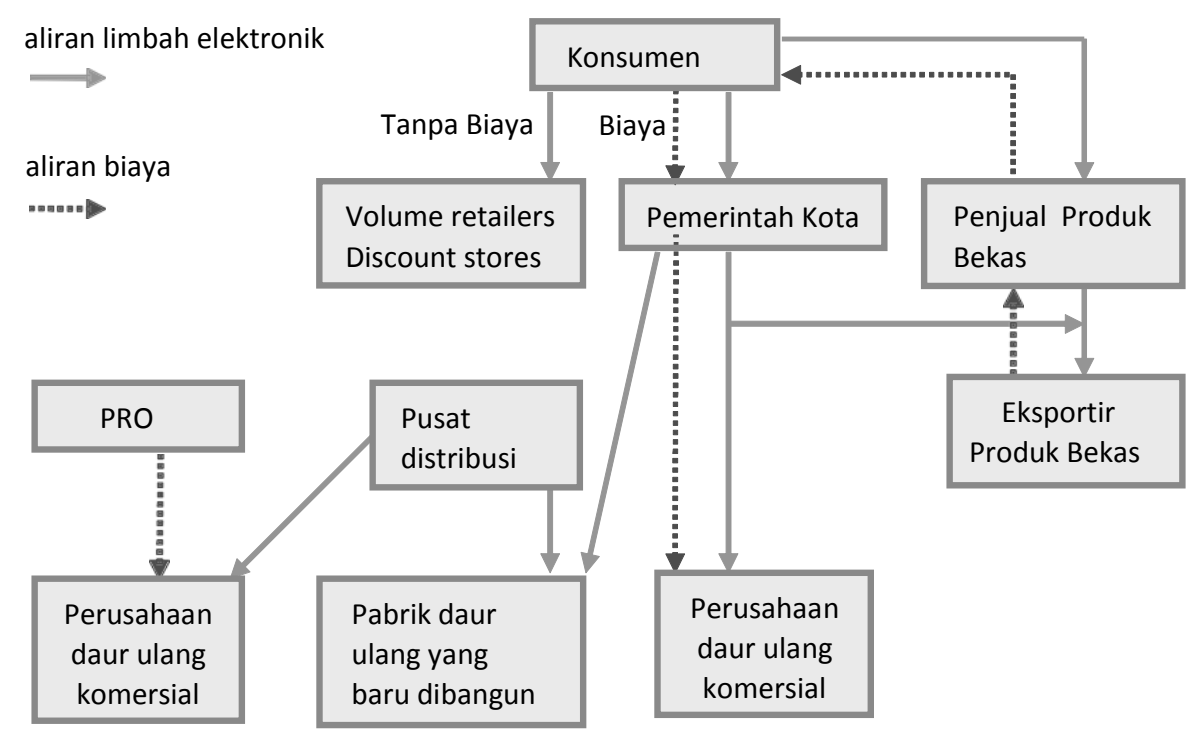

Gambar 3. Laju alir sampah elektronik di Korea Selatan 8].

Limbah elektronik termasuk ponsel dan CRT dilaporkan secara aktif diekspor ke negara-negara Asia Timur. Menurut Korea Custom and Trade Institute (KCTI), 305.460 televisi, 184.906 monitor, dan 951.077 CRT diekspor pada Tahun 2005 saja. Tidak adanya sistem pemantauan untuk memastikan bahwa 
barang-barang ini diperlakukan dengan baik atau tidak di negara pengimpor merupakan masalah yang mendesak [9]. Setiap produsen dapat memenuhi kewajiban hukum mereka dalam satu dari tiga cara. Salah satu caranya adalah dengan membangun pabrik daur ulang sendiri dan melakukan daur ulang sendiri. Cara lain adalah melakukan outsourcing pekerjaan ke perusahaan daur ulang komersial. Yang ketiga adalah bergabung dengan Organisasi Tanggung Jawab Produsen (PRO), membayar biaya yang diperlukan, dan meminta mereka melakukan daur ulang. Produsen dapat memilih opsi mana yang paling cocok untuk mereka. Ketika konsumen membuang limbah elektronik ke rute kota di bawah sistem PDR, mereka biasanya membayar biaya tertentu (3.000 hingga 10.000 won) sesuai dengan jenis barangnya [10].

\section{c. Taiwan}

\section{Latar Belakang Perundang-undangan}

Taiwan memiliki peraturan yang disebut Administrasi Perlindungan Lingkungan (EPA). Karena di Taiwan saat itu masih melakukan pengolahan secara tradisional. Sebagai contoh cara yang dilakukan ialah mengekstraksi logam dengan membakar bagian yang bukan logam dan atau memurnikan logam dengan bahan kimia. Tentu ini akan berdampak buruk terhadap lingkungan, termasuk polusi udara yang disebabkan oleh pembakaran, pencemaran air dan tanah serta pembuangan bagian yang tidak terpakai secara tidak tepat.

Dalam hal ini, EPA berupaya untuk mengurangi terjadinya polusi lingkungan dengan memperkenalkan sistem daur ulang yang dipimpin dan dipantau langsung oleh pemerintah. Taiwan memperkenalkan Sistem Komite Pengelolaan Dana Daur Ulang (RFMC), mirip dengan Korea Selatan, secara komprehensif untuk mengatur dan memisahkan masing-masing kategori limbah serta cara penanganannya. RFMC juga memastikan pengumpulan dan penggunaan sumber daya yang efisien bertujuan untuk mengurangi limbah

Struktur Pengumpulan dan Alokasi Biaya

Taiwan memperkenalkan sistem RFMC pada tahun 1998 untuk mengenalkan sistem daur ulang "(1) produk yang sulit diolah, (2) bahan berbahaya, dan (3) barang layak guna untuk pemulihan dan digunakan kembali." RFMC didirikan sebagai bagian dari EPA [11].

Di bawah sistem RFMC, produsen (termasuk pula importir) diwajibkan membayar biaya untuk mengumpulkan dan mendaur ulang limbah elektronik. Sistem pembayaran oleh produsen dilakukan secara akumulatif, yakni dengan perhitungan nilai jumlah penjualan tahun sebelumnya dikalikan dengan biaya untuk pengumpulan dan daur ulang per item untuk sampai pada total biaya yang harus dibayar. Biaya pengumpulan dan daur ulang diputuskan oleh Komite Peninjau Tingkat Biaya (FRRC), yang terdiri dari perwakilan pemerintah, produsen, konsumen, akademisi, dan sektor lainnya.

Dana tersebut sebagai sumber pendapatan RFMC yang akan diteruskan kepada organisasi yang ikut berpartisipasi dalam pengumpulan dan daur ulang limbah elektronik. Namun, hanya organisasi yang terdaftar dan aktif di lembaga audit yang dapat mengklaim dana tersebut. Dari (Gambar 4) organisasi yang tidak ikut serta dalam mendaur ulang tidak dihukum, dan tentu saja tidak dapat mengklaim subsidi dana (Gambar 5). Dengan kata lain, di bawah sistem RFMC, hanya produsenlah yang memiliki tanggung jawab besar untuk mengumpulkan dan mendaur ulang. Di bawah sistem RFMC, empat jenis peralatan rumah tangga bekas (televisi, lemari es, mesin cuci, dan AC) dan komputer pribadi bekas telah dipilih masing-masing sebagai satu kategori dalam sistem [12]. 


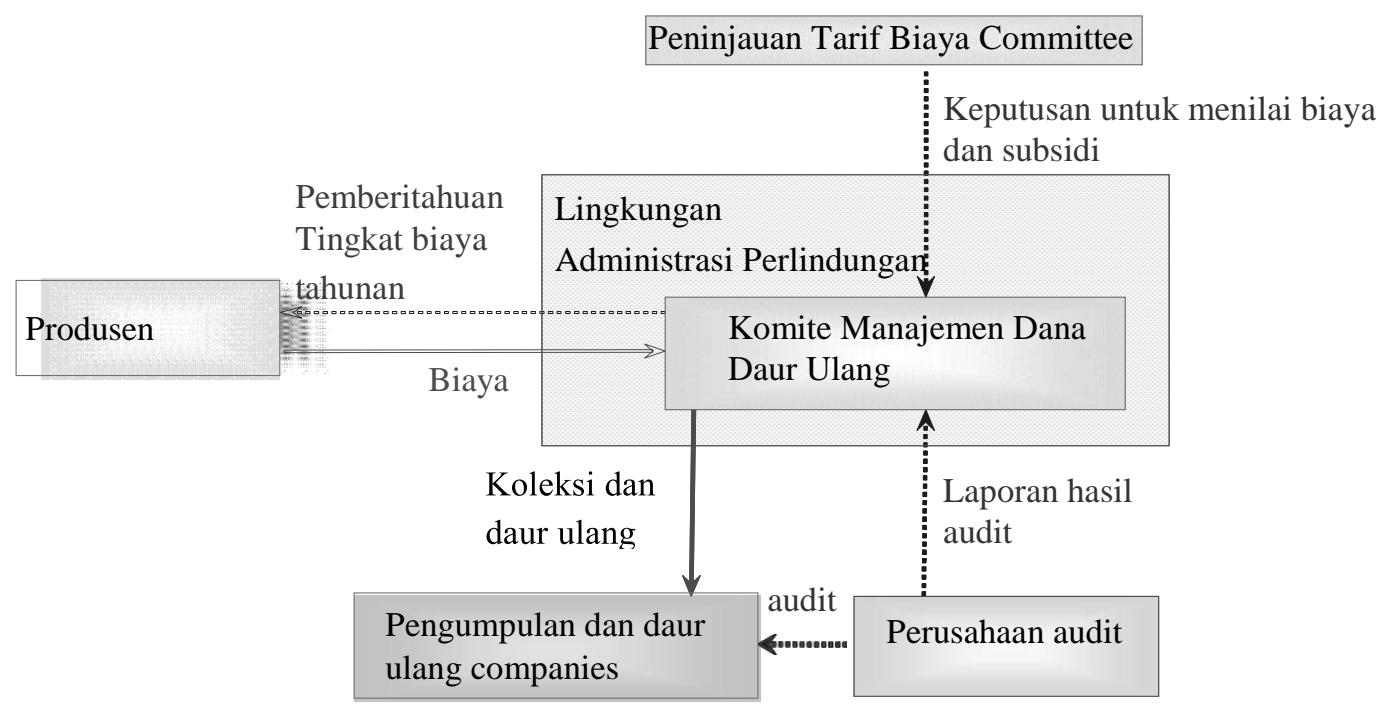

Gambar 4. Arus Dana dan Subsidi di Taiwan [13].

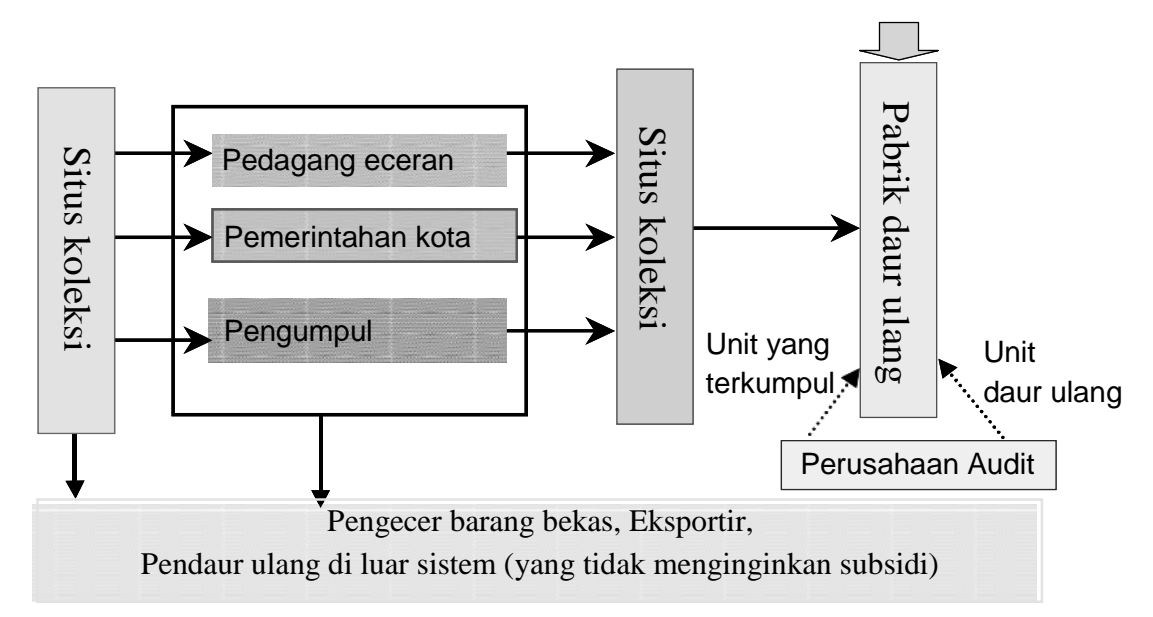

Gambar 5. Laju alir sampah elektronik dalam sistem RFMC in Taiwan [13].

\section{Studi Analisis dan Diskusi}

Dari hasil pembelajaran di atas, maka kami menyimpulkan bahwa cara yang paling baik untuk mengolah limbah elektronik adalah dengan terlebih dahulu melepaskan satu persatu komponenkomponennya lalu mengelompokkannya dengan membagi sesuai jenisnya. Setelah itu menggunakan kembali komponen-komponen yang masih layak pakai, sedangkan komponen-komponen yang sudah tidak layak digunakan atau sudah rusak dapat di daur ulang. Namun, sebelum mencapai kesana, bagaimana kita bisa mengumpulkan dengan membedakan sampah rumah tangga dengan sampah elektronik? Lalu komponen yang tidak dapat digunakan akan bagaimana kelanjutannya?

\section{Pemisahan tempat sampah antara sampah rumah tangga dengan sampah elektronik}

Sebagai masyarakat pada umumnya pastilah hanya mempunyai satu tempat atau tong sampah di depan rumah mereka masing-masing. Dalam tempat sampah tersebut akan berisikan berbagai macam benda, barang, sisa makanan dan lain-lain. Setelah itu akan ada pihak yang akan mengumpulkan dan membawa sampah-sampah setiap rumah menuju tempat pembuangan akhir. Pihak yang membawa ini sudah mempunyai kesepakatan dengan pihak perumahan atau RT/RW setempat.

Dengan demikian sampah elektronik masih bercampur dengan sampah rumah tangga. Penulis dalam hal ini memberikan solusi untuk memisahkan antara sampah elektronik dengan sampah rumah tangga dengan cara membuatkan tempat atau tong terpisah. Dalam arti lain ada dua tempat sampah yang akan tersedia. Pastinya akan ada pembeda diantara kedua tempat sampah tersebut.

Seperti yang dilakukan pada Kantor Dinas Lingkungan Hidup DKI Jakarta yang memiliki gerakan peduli lingkungan. Cara yang dipakai adalah memisahkan sampah elektronik dangan sampah komersil yang ada di kantor dengan menyediakan tempat sampah yang berbeda warna (Gambar 6). 


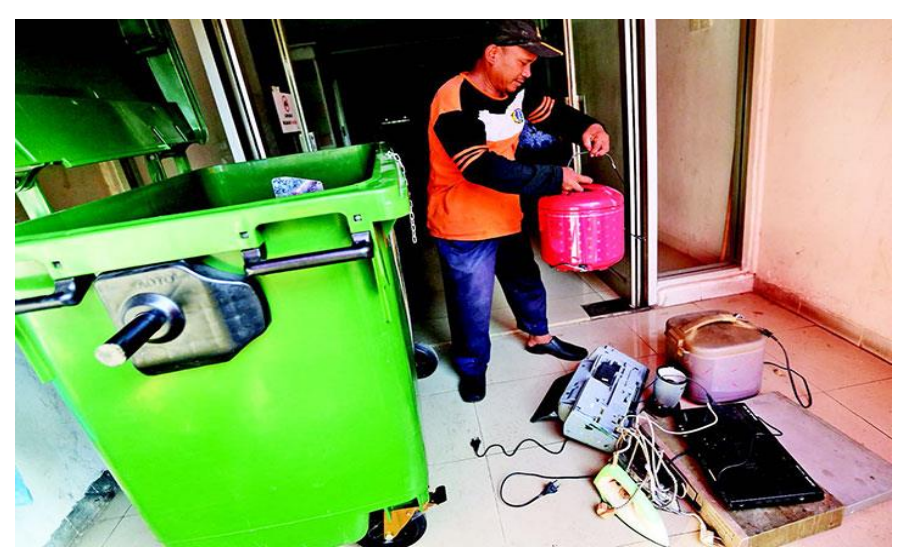

Gambar 6. Contoh tempat sampah khusus elektronik di kantor dinas lingkungan hidup DKI Jakarta [14].

Selain di kantor, program lainnya ialah menempatkan tempat sampah khusus elektronik pada titiktitik pusat keramaian, seperti area car free day, area apartemen, rusun, asrama di daerah DKI Jakarta. Sekitar 400 unit tempat sampah sudah dipasang di area tersebut. Tentu diperlukan edukasi dan sosialisasi terhadap masyarakat sekitar untuk tahu fungsi dari tempat sampah hijau tersebut. Dalam kampanye Greenpeace yang disampaikan oleh Ahmad Ashov Birry pada tahun 2014, Indonesia menghasilkan 745 kilo ton limbah elektronik dengan rata-rata per penduduk sebesar tiga kilogram. Sebanyak tiga juta metrik ton dari limbah tersebut berasal dari produk teknologi informasi berukuran kecil seperti ponsel. Namun hanya sekitar 16\% saja yang dapat didaur ulang dengan benar [14].

\section{Pengelolaan sampah berbasis seni kerajinan}

Menurut penulis, metode ini menjadi solusi kedua. Indonesia dikenal mempunyai banyak seniman. Ide-ide kreatif mereka bahkan sudah sampai ke kancah dunia internasional. Sebagai pemanfaatan, komponen yang tidak terpakai dapat disulap menjadi karya-karya yang unik dan memiliki nilai jual. Perlu peran serta pemerintah dan para seniman untuk mewujudkan ini. Pemerintah untuk mempersiapkan program sebagai wadah daya tampung hasil karya seni mereka.

\section{a. Limbah CD (compact disk) Bekas}

CD bekas dapat dimanfaatkan sebagai karya seni berupa kipas angin (Gambar 7), karya seni berwujud hewan (Gambar 8) dan lain sebagainya.

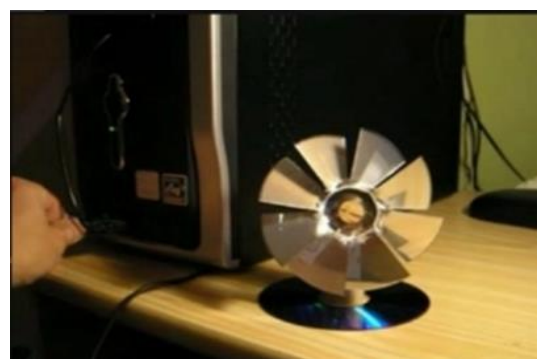

Gambar 7. Kaset CD menjadi baling-baling kipas angin [15].

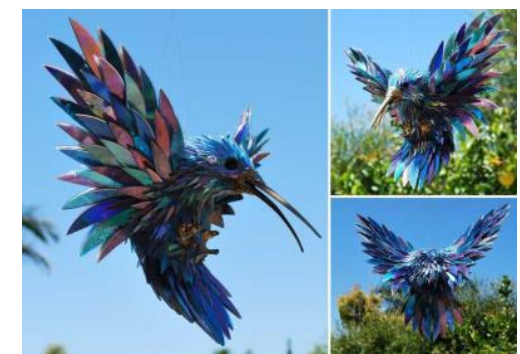

Gambar 8. Kaset CD menjadi karya seni menyerupai burung [16].

\section{b. Limbah PCB}

PCB menjadi salah satu komponen yang pasti ada di setiap komponen elektronik, bahkan memakan banyak tempat dalam produk elektronik. Oleh karena itu, pemanfaatan PCB sebagai seni akan melengkapi kecanggihan teknologinya. PCB memudahkan pecinta seni agar dapat menciptakan pola yang baik 
dengan berbagai dimensi yang dapat menghasilkan berbagai macam bentuk, misalnya karya seni yang menyerupai hewan serangga seperti yang ditunjukkan oleh Gambar 9.

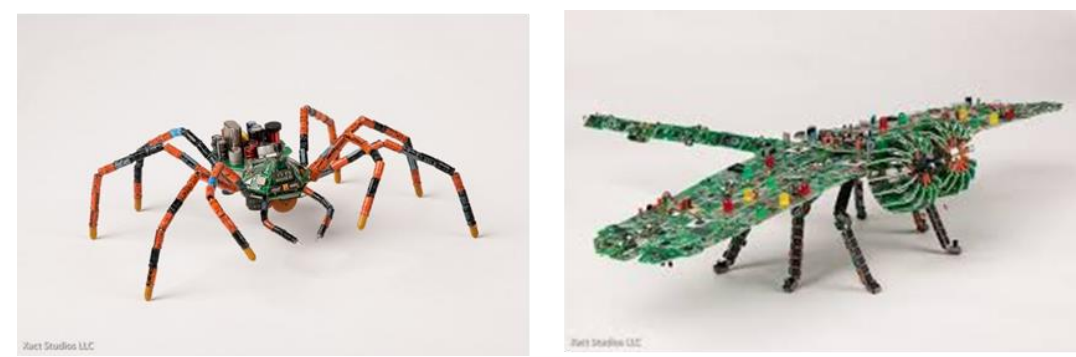

Gambar 9. PCB menjadi bentuk karya seni menyerupai serangga [17].

\section{Kesimpulan}

Limbah elektronik di Indonesia masih kurang dikelola dengan baik. Kebanyakan masyarakat mengolahnya dengan cara daur ulang, reparasi, ekspor, hingga penguburan. Namun, good-newsnya bahwa seharusnya dapat dikelola dengan maksimal karena limbah elektronik memiliki nilai ekonomis yang tinggi jika diolah (ditangani) dengan baik. Terlebih lagi, rendahnya nilai ekonomis pada komponenkomponen elektronik yang tidak dapat didaur ulang maupun di reparasi, yang pada akhirnya hanya di kubur saja. Penanganan yang tepat seperti yang diajukan pada artikel ini sebaiknya bisa segera diterapkan oleh pemerintah maupun masyarakat yaitu dengan memanfaatkan limbah elektronik menjadi barang kerajinan yang memiliki nilai ekonomis yang lebih tinggi dibandingkan dibuang begitu saja.

\section{Ucapan terima kasih}

Para penulis berterima kasih kepada artikel-artikel yang ditulis oleh penulis-penulis atau perisetperiset sebelumnya sehingga sangat membantu kami dalam penelitian dan penulisan artikel ilmiah ini.

\section{Singkatan}

LPUR

LRHA

CRT

OECD

PRO

FRRC

RFMC

EPA

EPR

LRSR

\author{
Law for the Promotion of Effective Utilization of Resources \\ Law for the Recycling of Specified Kinds of Home Appliances \\ Color Cathode Ray Tubes \\ Organization for Economic Co-operation and Development \\ Producer Responsibility Organization \\ Fee Rate Reviewing Committee \\ Recycling Fund Management Committee \\ Environment Protection Administration \\ Extended Producer Responsibility \\ Law for Promotion of Resources Saving and Reutilization
}

\section{Referensi}

[1] F. Syifaul, "Electronic Art: Solusi Sampah Elektronika," Majalah KOMUNIKASI, Kolom Opini, (ISSN: 0215-7632) Hal. 11, Tahun 36, Nomor 290, Januari-Februari 2014.

[2] Shagun, Ashwani Kush, and Anupam Arora, "Proposed Solution of e-Waste Management" [International Journal of Future Computer and Communication] vol. 2, No. 5, October 2013.

[3] AEHA (Association of Electric Home Appliances), "Kankyo sogo handobukku: Kaden kyokai no kankyo mondai eno torikumi" (in Japanese) / "Handbook of environment integration: Environmental measures by the electrical industr" (in English), 1998.

[4] S.W. Chung and R.M. Suzuki, "A Comparative study of e-waste recycling systems in Japan, South Korea and Taiwan from the EPR perspective: Implications for developing countries," 2008.

[5] F. Yoshida, "The Cyclical Economy of Japan 78", Hokkaido University Press, Sapporo, 2005.

[6] H. Yutaka, "Recycle system of specified kinds of home appliances: The structure of two groups". Oikonomika [The Society of Economics of Nagoya City Uni- versity] 40, No. 1: 1-22, 2003.

[7] J. J. Rhee and H. S. Jeong, "Dynamics of Environmental Policy Development in Korea: How Did the Policy Window Have Been Open?", Study of Environmental Policy [Korea Environment Institute] 2, No.1, p. 29, 2003.

[8] KORECO (Korea Recycling Corporation), "Pegimul Yotikinn Seido wa Gokum Kwanri Unyong Beban e Gwanhan Zosa" (in Korean) / "Investigation On Producer Deposit-refund System and 
Management of Unreturned Deposit” (in English), pp. 119-120, 1990.

[9] KCTI (Korea Custom and Trade Institute), "Zunggo Zunzazepum u Suchul e Ganhan Bogosu” (in Korean) / "Report on export of secondhand home appliances" (in English), 2006.

[10] Kim, K. R, "Pegimul Balseng Yukze Jungchek u Pyongga wa Baljeon Banhyang" (in Korean) / Evaluation of waste reduction policy and development plan" (in English), 1998.

[11] N.K. Chosa Kyogikai, "Shigen risaikuru ni kansuru seisaku fureimu no keisei ni mukete" (in Japanese) / "Toward formation of policy framework for resource recycling" (in English), pp. 94-95, 2000.

[12] C. Chiung-Ting and S. Dai-Gee, "Evolution of Recycling Programs in Taiwan", Kyoto University, March 9-10, 2000.

[13] Murakami, Rie. 2005. "Nihon Taiwan Kankoku ni okeru shiyozumi kaden no shori risaikuru o chushin to shita haikibutsu seisaku" (in Japanese) / "Waste recycling policy on used home appliances in Japan, South Korea and Taiwan" (in English). Doctoral dissertation, Kyushu University.

[14] http://m.mediaindonesia.com/read/detail/102659-ramai-ramai-kumpulkan-sampah-elektronik, (diakses pada tanggal 19 Maret 2020).

[15] https://gimanacaranya.wordpress.com/2011/01/27/membuat-kipas-angin-dari-cd-bekas-dandicolok-pake-usb/ (diakses pada tanggal 19 Maret 2020).

[16] https://www.provoke-online.com/index.php/art/artnews/12650-whooaa-kepingan-cd-bekas-bisajadi-karya-seni-secakep-ini (diakses pada tanggal 19 Maret 2020).

[17] http://allsuccessful.blogspot.com/2012/02/pic-karya-seni-dari-pcb-oleh-steven.html (diakses pada tanggal 19 Maret 2020). 